\title{
Investigating myocardial work as a CRT response predictor is not a waste of work
}

Citation for published version (APA):

Prinzen, F. W., \& Lumens, J. (2020). Investigating myocardial work as a CRT response predictor is not a waste of work. European Heart Journal, 41(39), 3824-3826. https://doi.org/10.1093/eurheartj/ehaa677

Document status and date:

Published: 14/10/2020

DOI:

10.1093/eurheartj/ehaa677

Document Version:

Publisher's PDF, also known as Version of record

Document license:

Taverne

Please check the document version of this publication:

- A submitted manuscript is the version of the article upon submission and before peer-review. There can be important differences between the submitted version and the official published version of record.

People interested in the research are advised to contact the author for the final version of the publication, or visit the DOI to the publisher's website.

- The final author version and the galley proof are versions of the publication after peer review.

- The final published version features the final layout of the paper including the volume, issue and page numbers.

Link to publication

\footnotetext{
General rights rights.

- You may freely distribute the URL identifying the publication in the public portal. please follow below link for the End User Agreement:

www.umlib.nl/taverne-license

Take down policy

If you believe that this document breaches copyright please contact us at:

repository@maastrichtuniversity.nl

providing details and we will investigate your claim.
}

Copyright and moral rights for the publications made accessible in the public portal are retained by the authors and/or other copyright owners and it is a condition of accessing publications that users recognise and abide by the legal requirements associated with these

- Users may download and print one copy of any publication from the public portal for the purpose of private study or research.

- You may not further distribute the material or use it for any profit-making activity or commercial gain

If the publication is distributed under the terms of Article $25 \mathrm{fa}$ of the Dutch Copyright Act, indicated by the "Taverne" license above, 


\title{
Investigating myocardial work as a CRT response predictor is not a waste of work
}

\author{
Frits W. Prinzen* and Joost Lumens $(\mathbb{D}$ \\ Departments of Physiology and Biomedical Engineering, Cardiovascular Research Institute Maastricht (CARIM), Maastricht University, Maastricht, The Netherlands
}

Online publish-ahead-of-print 18 September 2020

\section{This editorial refers to 'Targeting septal work and viability identifies responders to cardiac resynchronization therapy’ ${ }^{\dagger}$, by J.M. Aalen et al., on page 3813.}

In this issue of the European Heart Journal, Aalen et al. report on a prospective study to explore the use of regional left ventricular (LV) myocardial work differences as a predictor of response to cardiac resynchronization therapy $(\mathrm{CRT})$. $^{1}$

The concept behind determination of myocardial work as a predictor of CRT response stems from the characteristic contraction patterns in dyssynchronous hearts. Early-activated regions start to shorten before aortic valve opening, thereby stretching later activated regions (Figure 1, blue arrows). This early systolic stretching makes the late-activated regions contract more forcefully due to the local Frank-Starling effect. This stronger contraction causes midsystolic stretching of the earlier activated regions ${ }^{2}$ (Figure 1, red arrows). Simultaneous invasive measurement of LV pressure and non-invasive measurement of myocardial strains showed low, and sometimes negative, work in early-activated regions and enhanced myocardial work in late-activated regions in animal models and computer simulations of ventricular pacing ${ }^{3,4}$ and left bundle branch block (LBBB). ${ }^{5,6}$ Later work of the Oslo group redefined the negative work, characterized by a typical clockwise course of the pressure-strain loop (Figure 1, red area), as 'wasted' work. ${ }^{7}$ A next important step towards clinical application, i.e. the development of a non-invasive way to assess LV pressure, was developed by the same group. ${ }^{8}$ It was shown that peak systolic arterial pressure, measured using the armcuff method, in combination with timing of opening and closure of the cardiac valves, using echo-Doppler, provides a reliable systolic part of the LV pressure curve that can be used to plot strain against, and thus non-invasively determine, regional myocardial work.

The prospective randomized trial, ${ }^{1}$ performed in 200 patients recruited in five European centres, is a logical next step to evaluate the clinical usefulness of myocardial work to select patients who benefit from CRT. The investigators show that the difference between myocardial work performed by the septum (S) and LV lateral wall (LW) predicted CRT response (defined as LV end-systolic volume reduction $>15 \%$ after 6 months) with an area under the curve (AUC) of 0.77 [ $95 \%$ confidence interval $(\mathrm{Cl}) 0.70-0.84$ ]. The predictive value was further increased by adding information on septal scar as obtained by magnetic resonance imaging (MRI) late enhancement in a subpopulation of patients [AUC 0.88 (95\% Cl 0.81-0.95)]. Importantly, predictive value was as good in patients with QRS duration 120-150 ms as in the entire cohort. Equally important is the observation that work difference alone and combined with septal viability predicted long-term survival without heart transplantation with a hazard ratio $(\mathrm{HR})$ of $0.36(95 \% \mathrm{Cl} 0.18-0.74)$ and $0.21(95 \% \mathrm{Cl}$ $0.072-0.61)$, respectively. Myocardial work is determined objectively and hardly depends on the user, in contrast to, for example, apical rocking and septal flash. The feasibility of the work analysis is undoubtedly high (98\%) due to the use of only the basal and mid-LV S and LW segments in the four-chamber view.

\section{What makes myocardial work such a good predictive measure?}

We believe the strongest fundament for the predictive power of the S-LW work difference lies in the fact that it incorporates the intraventricular difference in strain morphology. It is the typical pattern of contralateral S-LW interactions that causes the S-LW work difference in a heart with LBBB. Importantly, this mechanical behaviour of contralateral stretching and shortening is not only indicative for an electrical activation delay, it also strongly indicates good contractile function of the myocardium. In other words, the septal wall can only be stretched during systole when the LW is strong enough to do so. As a result, a large S-LW work is indicative of the combination of

\footnotetext{
The opinions expressed in this article are not necessarily those of the Editors of the European Heart Journal or of the European Society of Cardiology.

$\dagger$ doi:10.1093/eurheartj/ehaa603.

* Corresponding author. Department of Physiology, Cardiovascular Research Institute Maastricht, Universiteitssingel 50, 6229 ER Maastricht, The Netherlands. Tel: +31 4338 81080/81200, Fax: +31 4338 84166, Email: frits.prinzen@maastrichtuniversity.nl

Published on behalf of the European Society of Cardiology. All rights reserved. @ The Author(s) 2020. For permissions, please email: journals.permissions@oup.com.
} 


\section{$\mathrm{SSI}=\mathrm{SPS}_{\text {lat }}+\mathrm{SRS}_{\text {sept }}$}

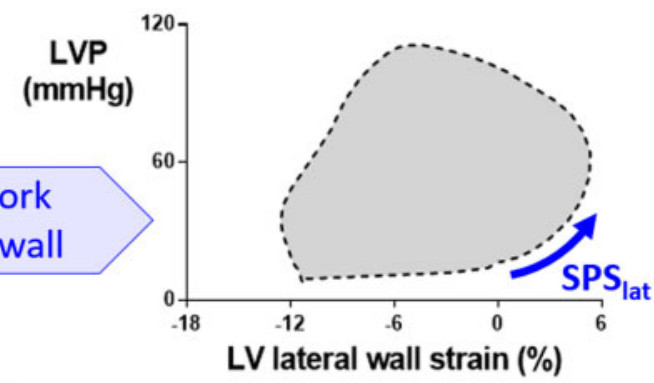

Strain

(\%)

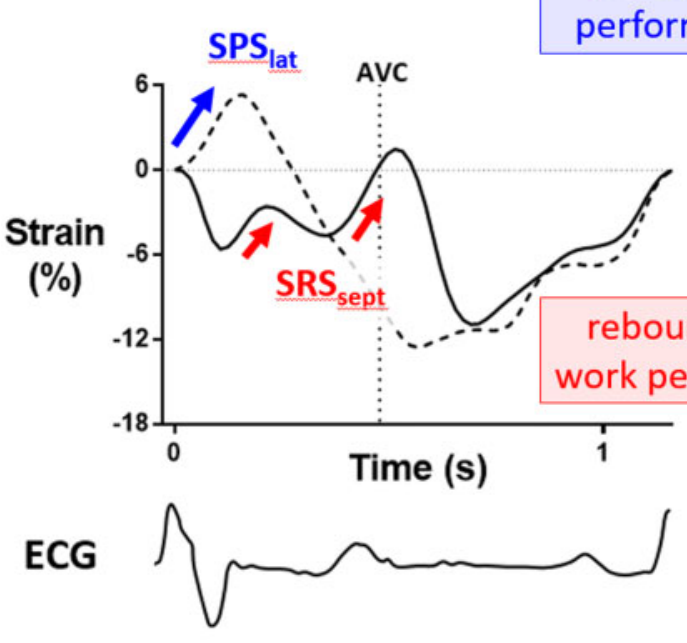

.... LV lateral wall

- Septum

Positive work $\square$ Negative work

rebound stretch decreases

work performed by septal wall

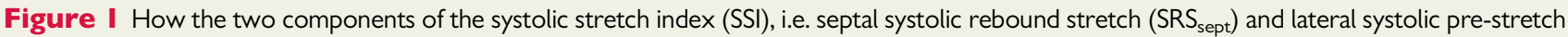
$\left(\mathrm{SPS}_{\text {lat }}\right)$, are related to the septal-to-lateral myocardial work difference in patients with LBBB. Note that systolic rebound stretch of the early-activated septal wall is causing the negative 'wasted' work, while systolic pre-stretch causes myocardial work to be increased in the late-activated lateral wall. Illustrations are adapted from Aalen et al. ${ }^{1}$ LVP, left ventricular pressure.

gross S-LW electrical dyssynchrony and good overall myocardial viability and contractile function.

Gross electrical dyssynchrony is typical for LBBB and similar conduction abnormalities, such as considerable fascicular blocks. To this purpose, the ECG can also be used. However, QRS duration provides insufficient information on non-electrical myocardial disease substrates, and criteria for LBBB are complicated, variable, and subjective.' Recently QRSarea obtained with vectorcardiography appeared as a promising electrical indicator, with a HR of 0.50 for survival without heart transplant in an $\sim 1500$ patient retrospective study. ${ }^{10}$ However, QRSarea can only partially assess the other requirement for large differences in myocardial work: viability. The results from the Aalen study suggest that the S-LW work difference incorporates the involvement of LW scar. However, additional information of septal scar from MRI is needed to improve CRT response prediction. The latter may be explained by the fact that in LBBB hearts, septal strain amplitudes are low, and thus hard to distinguish from scar.

The use of the S-LW work difference as an index for CRT selection fits the paradigm of using parameters of mechanical discoordination rather than of mechanical dyssynchrony. Parameters of mechanical dyssynchrony were initially used for CRT response prediction, but no randomized study was able to show the benefit of measuring time-to-peak shortening or velocity beyond ECG markers for CRT selection. Several studies combining computer simulations with clinical data have shown that S-LW differences in time-to-peak shortening or motion are rather aspecific and unable to differentiate between electrical and mechanical substrates of mechanical discoordination. ${ }^{11,12}$ The definition of septal peak shortening, in particular, was shown to be sensitive to subjective interpretation.

In their study, Aalen et al compared the predictive power of SLW work difference with that of other indices of mechanical discoordination, i.e. septal flash, apical rocking, and systolic stretch index (SSI; Figure 1). All these measures are based on very similar mechanistic grounds, so any differences in predictive power are unlikely to originate from their theoretical background. The arrows in the figure illustrate that the two kinds of systolic stretch, making up SSI, are directly related to the widening of the LW workloop and the clockwise $\mathrm{S}$ workloop. Although the authors claim that $\mathrm{S}$ LW work difference predicted CRT response better than SSI, it is important to mention that this conclusion is drawn from the analysis with LV reverse remodelling as the CRT response definition. The authors do not report any differences between the associations of S-LW work difference and SSI with clinical outcome after CRT. In a recent study, ${ }^{13} \mathrm{SSI}$ analysis was prospectively applied to an existing CRT trial database, including 478 patients from 94 international sites, reflecting a real-world clinical setting. High SSI was strongly associated with good clinical outcome after CRT, in patients with both class I and class II guideline indications for CRT. HRs indicated associations between SSI and clinical outcome of the same order of magnitude, or even better, than those between S-LW work difference and outcome reported by Aalen et al., and it should be noted that in that analysis neither MRI late enhancement nor pressure estimation were required. 
While the authors are to be complemented on this study, its limitations should also be recognized. An important limitation is that only 125 of the 200 patients underwent an MRI scan, of whom had 61 any scar. Given the fact that the authors distinguished scar between four regions, the number of patients with septal scar is probably much lower. So the 'added value' of septal scar was established in only a minority of patients. Also, the subanalysis of the patients with QRS duration between 120 and 150 ms is based on analysis of 44 patients (27 for those with late gadolinium enhancement cardiac MRI). Therefore, conclusions should be drawn with care.

What would be the way to go? To convincingly prove the advantage of imaging for CRT response prediction, a prospective study of much larger size is needed. The larger size would allow evaluation of the value of imaging in class I and II patients separately as well as in other subcategories, such as patients with (septal) scar. In such a study, some of the other echocardiographic indicators used, such as septal flash, apical rocking, and SSI, should also be included, as well as ECG markers. Importantly, in order to prove that the approaches tested are effective and have additional value beyond the ECG markers, data should be analysed by an echocardiographic core lab as well as by all individual centres separately. This is because the various echocardiographic markers may differ in user dependency. In the Aalen study, the simpler septal flash and apical rocking turned out to be equally good predictors as S-LW work difference, but this may be related to the fact that the analyses were performed in expert core labs. Only if the analysis by all individual centres also proves that one or more mechanical and/or scar imaging modalities does improve CRT response prediction beyond the use of ECG markers, such measurements may be ready to be included in the guidelines for CRT, which currently do not contain any advice on the assessment of mechanical dyssynchrony or discoordination.

In conclusion, the study reported by Aalen et al. provides a strong extension of our understanding of CRT response. It is not a waste of work to perform a larger prospective study to prove the clinical feasibility and benefit of a meaningful measure of LV mechanical discoordination, such as S-LW work difference or SSI, as an important additional selection criterion for CRT in the real-world setting.

\section{Acknowledgements}

J.L. acknowledges support from the Dr. Dekker Program of the Dutch Heart Foundation (grant 2015T082) and the Netherlands Organisation for Scientific Research (NWO- ZonMw, VIDI grant 016.176.340).

Conflict of interest: F.W.P. received or receives research grants from Medtronic, Abbott, Biotronik, Microport CRM, Pie Medical
Imaging, and EBR Systems. J.L. received research grants from Medtronic.

\section{References}

1. Aalen JM, Donal E, Larsen CK, Duchenne J, Lederlin M, Cvijic M, Hubert A, Voros G, Leclercq C, Bogaert J, Hopp E, Fjeld JG, Penicka M, Linde C, Aalen OO, Kongsgård E, Galli E, Voigt J-U, Smiseth OA. Targeting septal work and viability identifies responders to cardiac resynchronization therapy. Eur Heart J 2020;41:3813-3823.

2. Prinzen FW, Augustijn $\mathrm{CH}$, Arts T, Allessie MA, Reneman RS. Redistribution of myocardial fiber strain and blood flow by asynchronous activation. Am J Physiol 1990;259: $\mathrm{H} 300-\mathrm{H} 308$.

3. Prinzen FW, Hunter WC, Wyman BT, McVeigh ER. Mapping of regional myocardial strain and work during ventricular pacing: experimental study using magnetic resonance imaging tagging. J Am Coll Cardiol 1999;33:1735-1742.

4. Walmsley J, Arts T, Derval N, Bordachar P, Cochet H, Ploux S, Prinzen FW, Delhaas $T$, Lumens J. Fast simulation of mechanical heterogeneity in the electrically asynchronous heart using the MultiPatch module. PLoS Comp Biol 2015;11: e1004284.

5. Vernooy K, Verbeek XA, Peschar M, Crijns HJ, Arts T, Cornelussen RN, Prinzen FW. Left bundle branch block induces ventricular remodelling and functional septal hypoperfusion. Eur Heart J 2005;26:91-98.

6. Lumens J, Ploux S, Strik M, Gorcsan JRCochet H, Derval N, Strom M, Ramanathan C, Ritter P, Haïssaguerre M, Jaïs P, Arts T, Delhaas T, Prinzen FW, Bordachar P. Comparative electromechanical and hemodynamic effects of left ventricular and biventricular pacing in dyssynchronous heart failure: electrical resynchronization versus left-right ventricular interaction. J Am Coll Cardiol 2013; 62:2395-2403.

7. Russell K, Eriksen M, Aaberge L, Wilhelmsen N, Skulstad H, Gjesdal O, Edvardsen T, Smiseth OA. Assessment of wasted myocardial work: a novel method to quantify energy loss due to uncoordinated left ventricular contractions. Am J Physiol Heart Circ Physiol 2013;305:H996-H1003.

8. Russell K, Eriksen M, Aaberge L, Wilhelmsen N, Skulstad H, Remme EW, Haugaa KH, Opdahl A, Fjeld JG, Gjesdal O, Edvardsen T, Smiseth OA. A novel clinical method for quantification of regional left ventricular pressure-strain loop area: a non-invasive index of myocardial work. Eur Heart J 2012;33:724-733.

9. van Stipdonk AMW, Hoogland R, Ter Horst I, Kloosterman M, Vanbelle S, Crijns HJGM, Prinzen FW, Meine M, Maass AH, Vernooy K. Evaluating electrocardiography-based identification of cardiac resynchronization therapy responders beyond current left bundle branch block definitions. JACC Clin Electrophysiol 2020;6:193-203.

10. van Stipdonk AMW, Ter Horst I, Kloosterman M, Engels EB, Rienstra M, Crijns HJGM, Vos MA, van Gelder IC, Prinzen FW, Meine M, Maass AH, Vernooy K. QRS area is a strong determinant of outcome in cardiac resynchronization therapy. Circ Arrhythm Electrophysiol 2018;11:e006497.

11. Lumens J, Leenders GE, Cramer MJ, De Boeck BW, Doevendans PA, Prinzen FW, Delhaas T. Mechanistic evaluation of echocardiographic dyssynchrony indices: patient data combined with multiscale computer simulations. Circ Cardiovasc Imaging 2012;5:491-499.

12. Lumens J, Tayal B, Walmsley J, Delgado-Montero A, Huntjens PR, Saba S, Delhaas T, Prinzen FW and Gorcsan r]. Differentiating the electromechanical substrate responsive to cardiac resynchronization therapy from non-electrical dyssynchrony substrates by computer-assisted regional strain analysis. Circ Cardiovasc Imaging 2015;8:e003744.

13. Gorcsan J 3rd, Anderson CP, Tayal B, Sugahara M, Walmsley J, Starling RC, Lumens J. Systolic stretch characterizes the electromechanical substrate responsive to cardiac resynchronization therapy. JACC Cardiovasc Imaging 2019;12: 1741-1752. 